\title{
Thin layer drying behaviour of fermented cocoa (Theobroma cacao L.) beans
}

\section{Mujaffar, S..$^{\text {* }}$; Ramroop, A. ${ }^{\text {; }}$; Sukha, D. ${ }^{\mathrm{c}}$}

${ }^{a}$ Food Science and Technology Unit, Department of Chemical Engineering, The University of the West Indies, St. Augustine, Trinidad and Tobago, West Indies. Tel.:+1 8686622002 Extension 82190.

b Cocoa Research Centre, The University of the West Indies, St. Augustine, Trinidad and Tobago, West Indies.

*E-mail of the corresponding author: saheeda.mujaffar@sta.uwi.edu

\begin{abstract}
To assess the impact of a rest interval and bean turning on the thin-layer drying behavior of fermented cocoa beans, beans of mixed Trinitario varieties were dried in a cabinet oven at three temperatures $\left(40,50,60^{\circ} \mathrm{C}\right)$ using three drying regimes, namely; continuous drying, intermittent drying (drying for $8 \mathrm{~h}$ with a rest period of 16h), and intermittent drying with turning of beans. Moisture content, water activity, $\mathrm{pH}$ and colour attributes were measured and sensory evaluation of the cocoa liquor carried out on selected samples. Drying curves were constructed and drying rate constants ( $k$ ) and effective diffusivity $\left(D_{\text {eff }}\right)$ values determined.
\end{abstract}

Keywords: Oven-drying; Fick's Law; Rate constant; Diffusion coefficient 


\section{Introduction}

Drying of fermented beans is an important step in the primary processing of cocoa (Theobroma cacao L.) beans, which are dried to reduce the moisture content from about $60 \%$ to $6-7 \%$ for safe storage and transportation. During drying, oxidative chemical reactions that occur during fermentation to reduce the astringency and bitterness of the bean continue $^{[1]}$. The rate of drying and the final moisture content of dried beans have a direct impact on bean quality and value-added products such as cocoa liquors and chocolates. Too rapid drying can result in the formation of a physical barrier to moisture and volatile acid movement, resulting in brittle beans with high acidity. Too slow drying can favour mould growth during storage and handling.

Sun-drying of cocoa beans is the most widely practiced method of drying due to the simplicity and use of natural energy. Sun-drying is, however, weather dependent, requires large areas of floor space and is labour intensive as the beans must be frequently mixed during drying. Artificial drying systems are used to shorten drying time and increase the rate of moisture removal from the beans ${ }^{[2,3,4,5,6,7]}$. The negative effects of rapid drying are thought to be alleviated during traditional sun-drying due to the low drying temperatures experienced, the regular turning of beans to ensure uniform drying, and through a 'resting' period which takes place during the evening and night-time. The tempering or rest period is reported to assist with moisture redistribution in the beans before the next drying phase commences $^{[10]}$. For artificially dried beans, the risk of high bean acidity is exacerbated due to the typically high drying temperatures used ${ }^{[8,9,10]}$.

The objective of this study was to investigate the oven-drying of Trinitario (fine or flavor cocoa) beans at three temperatures $\left(40,50\right.$ and $\left.60^{\circ} \mathrm{C}\right)$, with the specific objective of comparing the drying behaviour and selected quality attributes of beans dried continuously with that of beans handled in a manner which simulates the traditional sun-drying practice, namely, a rest period with and without the turning of beans.

\section{Materials and Methods}

Fermented cocoa beans of mixed Trinitario varieties were obtained from the Cocoa Research Centre (CRC) cocoa processing facility and dried in a Unitemp Drying Cabinet (LTE Scientific Ltd., Greenfield, Oldham). Beans were dried at 40,50 and $60^{\circ} \mathrm{C}$. The relative humidity of the drying air at each of the three oven temperatures averaged 60,40 and $25 \%$, respectively and the air velocity was less than $0.5 \mathrm{~m} / \mathrm{s}$. Beans were weighed $(0.01 \pm 0.005 g)$ using an Ohaus Explorer Pro Balance, Model EP2102C (Ohaus Corporation, NJ, USA) and drying was continued until there was virtually no change in weight. For Continuous drying (CD), beans were placed into the oven and dried until constant weight 
was achieved. For Intermittent drying (ID), beans were allowed to dry at the respective temperatures for 8 hours, packaged and stored in a cool room $\left(24^{\circ} \mathrm{C}\right)$ for 16 hours and reloaded onto the trays the next morning. Beans were handled similarly for the last method; Intermittent with turning of beans (ID+Turn), with the additional turning (mixing) of beans at each weighing time. Bean moisture content, water activity $\left(\mathrm{a}_{\mathrm{w}}\right), \mathrm{pH}$ and colour was assessed as previously described ${ }^{[11]}$ and Hue angle $\left(^{\circ}\right)$ and Chroma were calculated as given in Equations 1 and $2^{[12]}$.

$$
\begin{aligned}
& \text { Hue }=\operatorname{Arctan}\left(\frac{b^{*}}{a^{*}}\right) \\
& \text { Chroma }=\sqrt{\left(a^{* 2}+b^{z^{2}}\right)}
\end{aligned}
$$

Drying rates and Moisture Ratio $(M R)$ values were calculated as described by Mujaffar et al. $^{[11]}$ and liqour samples produced from selected dried beans were assessed based on thirteen flavour attributes ${ }^{[13]}$.

\section{Results and Discussion}

The initial moisture content and water activity values of fermented bean samples ranged from 0.78 to $1.02 \mathrm{~g} \mathrm{H}_{2} \mathrm{O} / \mathrm{g} \mathrm{DM}$ (44 - 51\% wb) and 0.954 to 0.966 , respectively. Drying curves showing the change in moisture content with total drying time for each drying method for the range of temperatures are given in Figs. 1 (a) through (c).
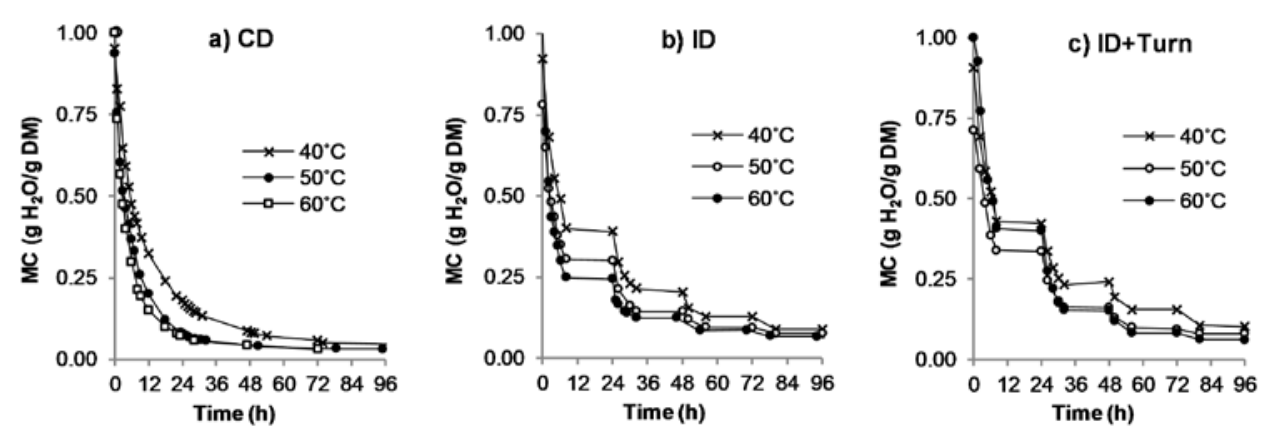

Figure 1. Drying curves for cocoa beans dried as a function of total drying time. CD-Continuous ID-Intermittent ID+Turn (Intermittent with Turning)

Moisture content during drying was significantly affected by total drying time, drying temperature, drying treatment and time-temperature, time-treatment and temperature 
treatment interactions $(p \leq 0.05)$. As also expected, the intermittent drying of beans (Figs. $1 \mathrm{~b}$ and c) resulted in a step-wise decrease in moisture values due to the rest period during which there was no drying. For continuously dried beans (Fig. 1a), the effect of increasing temperature on the decline in moisture was most evident during the first 24h of drying, with higher temperatures effecting a greater decline in moisture. Bean moisture content, water activity values and the time taken to reach equilibrium moisture content are given in Table 1. Given that the moisture content of $6-8 \%(\mathrm{wb})$ is the industry standard as the maximum safe storage limit for cocoa beans, the time taken for beans to attain a $7 \%$ moisture value is also given in Table 1.

Table 1. Moisture content, water activity values, time taken to reach equilibrium and $7 \%(w b)$ moisture content in dried cocoa beans.

\begin{tabular}{|c|c|c|c|c|c|c|c|}
\hline \multirow{2}{*}{$\begin{array}{l}\text { Temperature } \\
\left({ }^{\circ} \mathrm{C}\right)\end{array}$} & \multirow[t]{2}{*}{ Treatment } & \multirow{2}{*}{$\begin{array}{l}\text { MC } \\
\left(\mathrm{g} \mathrm{H}_{2} \mathrm{O} / \mathrm{g} \mathrm{DM}\right)\end{array}$} & \multirow[t]{2}{*}{$\mathbf{a}_{\mathbf{w}}$} & \multicolumn{2}{|c|}{$\begin{array}{l}\text { Time to Equilibrium } \\
\text { (h) }\end{array}$} & \multicolumn{2}{|c|}{$\begin{array}{l}\text { Time to } 7 \% \\
\text { MC (h) }\end{array}$} \\
\hline & & & & Total & Actual & Total & Actual \\
\hline \multirow{3}{*}{40} & CD & $0.040^{\mathrm{d}}$ & $0.569^{b}$ & $147^{\mathrm{e}}$ & $147^{\mathrm{a}}$ & $48^{\mathrm{d}}$ & $48^{\mathrm{a}}$ \\
\hline & ID & $0.046^{\mathrm{bc}}$ & $0.518^{\mathrm{d}}$ & $224^{\mathrm{a}}$ & $80^{c}$ & $102^{\mathrm{a}}$ & $38^{\mathrm{b}}$ \\
\hline & ID+Turn & $0.050^{\mathrm{ab}}$ & $0.530^{\mathrm{d}}$ & $224^{\mathrm{a}}$ & $80^{c}$ & $119^{\mathrm{a}}$ & $45^{\mathrm{a}}$ \\
\hline \multirow{3}{*}{50} & CD & $0.032^{\mathrm{e}}$ & $0.594^{\mathrm{a}}$ & $95^{f}$ & $95^{b}$ & $24^{\mathrm{e}}$ & $24^{\mathrm{d}}$ \\
\hline & ID & $0.051^{\mathrm{a}}$ & $0.487^{\mathrm{e}}$ & $200^{\mathrm{b}}$ & $72^{\mathrm{e}}$ & $80^{\mathrm{b}}$ & $32^{c}$ \\
\hline & ID+Turn & $0.048^{\mathrm{ac}}$ & $0.525^{\mathrm{d}}$ & $200^{\mathrm{b}}$ & $72^{\mathrm{e}}$ & $79^{\mathrm{bc}}$ & $31^{\mathrm{c}}$ \\
\hline \multirow{3}{*}{60} & $\mathrm{CD}$ & $0.030^{\mathrm{e}}$ & $0.551^{\mathrm{c}}$ & $72^{\mathrm{g}}$ & $72^{\mathrm{d}}$ & $13^{e}$ & $13^{e}$ \\
\hline & ID & $0.050^{c}$ & $0.521^{\mathrm{d}}$ & $174^{\mathrm{d}}$ & $64^{\mathrm{f}}$ & $62^{\text {cd }}$ & $27^{\mathrm{cd}}$ \\
\hline & ID+Turn & $0.030^{\mathrm{e}}$ & $0.465^{f}$ & $176^{c}$ & $56^{g}$ & $80^{\mathrm{b}}$ & $30^{c}$ \\
\hline
\end{tabular}

CD-Continuous ID-Intermittent ID+Turn (Intermittent with Turning)

Means in a column without a common superscript letter differ $(p<0.05)$

Total drying time (time to attain equilibrium moisture content) for beans dried continuously at $60^{\circ} \mathrm{C}$ was half that of beans dried at $40^{\circ} \mathrm{C}$. As expected, the drying of beans using intermittent drying (with and without turning) increased the total drying time approximately 1.5 -fold at $40^{\circ} \mathrm{C}, 2.0$-fold at $50^{\circ} \mathrm{C}$ and 2.5 -fold at $60^{\circ} \mathrm{C}$. Drying is enhanced at the higher temperatures, which favours increased moisture movement and increased drying potential of the air. The initial rapid decline in moisture content has been attributed to the higher moisture content of bean testa, due residual wet mucilage coating. As the testa dries and hardens, diffusion of moisture from the cotyledon to the outer surface of the bean is gradually restricted ${ }^{[14]}$. Compared with beans dried continuously, equilibrium moisture values were generally higher in intermittently dried beans (Table 1). For beans dried at $40^{\circ} \mathrm{C}$, there was a slightly greater decline in moisture content in the beans dried 
intermittently (ID) and with turning (ID+Turn), demonstrating that the rest period impacted positively on the decline in moisture at this temperature. No discernible drying treatment effect was observed for beans dried at 50 and $60^{\circ} \mathrm{C}$. Hii et al. ${ }^{[7]}$ also noted that the tempering period has little effect on the moisture reduction in beans dried at higher temperatures. The drying potential of the air at $40^{\circ} \mathrm{C}$ would be expected to be lower than at the higher temperatures, therefore, moisture redistribution to the surface of the bean during the rest period may have assisted the drying process. It is therefore likely that the rest interval improves moisture movement during traditional sun-drying due to the low temperatures (below $50^{\circ} \mathrm{C}$ ) experienced during sun-drying, as well as a deeper depth of beans, typically $0.05 \mathrm{~m}$, compared with the single layer of beans used in this study.

The drying rate constants $(k)$ were determined from the initial straight line portions of plots of $\ln$ free moisture (ln $M R$ ) as a function of actual drying time $(t)$. As given in Table 2, $k$ values increased as drying temperature increased $(p \leq 0.05)$ and there was a temperaturetreatment interaction effect $(p \leq 0.05)$. Generally, as temperature increased the $k$-value increased. Drying treatment (CD, ID, ID+Turn) did not appear to have a discernible impact on the $k$-value, which was expected as the $k$-values apply to the initial stages of the drying process. The temperature dependence of the $D_{\text {eff }}$ values and the activation energy for beans dried continuously was estimated from a plot of $\ln D_{\text {eff }}$ versus $1 / T$ with the $E_{a}$ value of $24.28 \mathrm{KJ} / \mathrm{mol}\left(R^{2}=0.9984\right)$ obtained for continuously dried beans (CD), $36.0 \mathrm{KJ} / \mathrm{mol}\left(R^{2}=\right.$ $0.9316)$, and $18.8 \mathrm{KJ} / \mathrm{mol}$ for intermittently dried beans with mixing (ID+Turn) $\left(R^{2}=\right.$ 0.9369).

Table 2. Drying rate constants ( $k$ ) and diffusion coefficients $\left(D_{\text {eff }}\right)$ for dried cocoa beans.

\begin{tabular}{llll}
\hline $\begin{array}{l}\text { Temperature } \\
\left({ }^{\circ} \mathbf{C}\right)\end{array}$ & Treatment & $\boldsymbol{K}(\mathbf{1} / \mathbf{m i n})$ & $\boldsymbol{D}_{\text {eff }}\left(\mathrm{m}^{2} / \mathrm{s}\right)$ \\
\hline $\mathbf{4 0}$ & $C D$ & $0.1260^{\text {bd }}$ & $3.55 \times 10^{-10}$ \\
& $I D$ & $0.1120^{\text {cd }}$ & $3.17 \times 10^{-10}$ \\
& ID+Turn & $0.0945^{\mathrm{d}}$ & $2.66 \times 10^{-10}$ \\
\hline $\mathbf{5 0}$ & $C D$ & $0.1650^{\mathrm{b}}$ & $4.65 \times 10^{-10}$ \\
& $I D$ & $0.1420^{\mathrm{bc}}$ & $4.01 \times 10^{-10}$ \\
& $I D+$ Turn & $0.1070^{\mathrm{cd}}$ & $3.02 \times 10^{-10}$ \\
\hline $\mathbf{6 0}$ & $C D$ & $0.2210^{\mathrm{a}}$ & $6.22 \times 10^{-10}$ \\
& $I D$ & $0.2590^{\mathrm{a}}$ & $7.30 \times 10^{-10}$ \\
& $I D+$ Turn & $0.1460^{\mathrm{bc}}$ & $4.11 \times 10^{-10}$ \\
\hline
\end{tabular}

CD-Continuous ID-Intermittent ID+Turn (Intermittent with Turning)

Means in a column without a common superscript letter differ $(p<0.05)$

${ }^{*} \mathrm{D}_{\text {eff }}=\mathrm{k}\left(4 \mathrm{~L}^{2} / \pi^{2}\right)$ where $\mathrm{L}=$ half thickness $0.005 \mathrm{~m}$ 
At the end of drying of beans to equilibrium moisture content, there were no major visible differences in colour or appearance, although beans dried at $40^{\circ} \mathrm{C}$ generally appeared to be lighter in colour compared with beans dried at $50^{\circ} \mathrm{C}$, and beans dried at $60^{\circ} \mathrm{C}$ looked slightly shrivelled. For all the drying treatments, $\mathrm{pH}$ values (of both testa and cotyledon) were generally higher in beans dried continuously at $50^{\circ} \mathrm{C}$ and lowest at $60^{\circ} \mathrm{C}$ (Fig.2). High acidity of beans dried continuously at $60^{\circ} \mathrm{C}$ was reduced through intermittent drying (with or without turning), as evidenced by a significant $(p \leq 0.05)$ increase in $\mathrm{pH}$ values. It has been recommended that drying of beans be performed at bean temperatures not exceeding $60^{\circ} \mathrm{C}$ to avoid retention of excessive acids ${ }^{[15]}$.

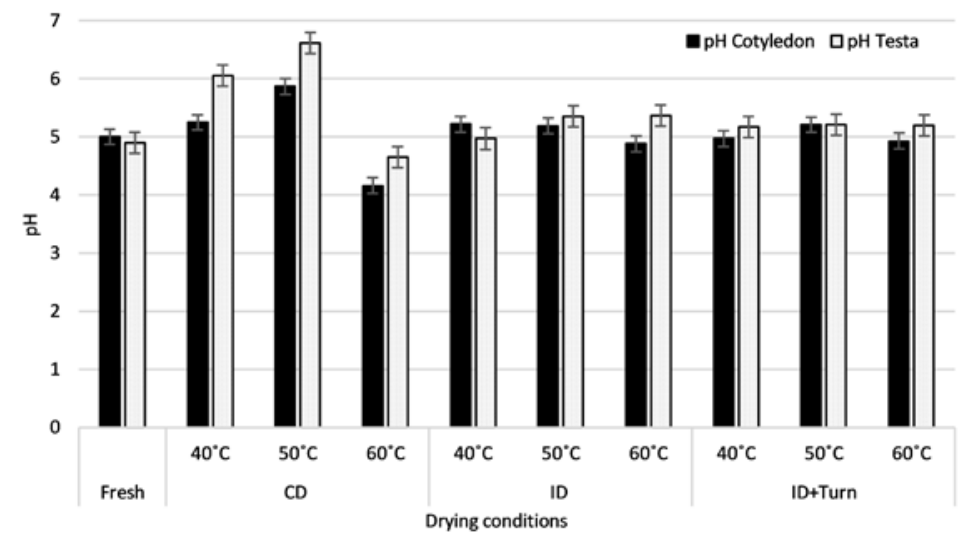

Fig. 2. pH values of bean testa and cotyledon

\section{CD-Continuous ID-Intermittent ID+Turn (Intermittent with Turning)}

While trends in $L^{*}, a^{*}$, Hue and Chroma values were not apparent, it was noted that colour attribute values were lower in all beans dried at $40^{\circ} \mathrm{C}$. For beans dried at $50^{\circ} \mathrm{C}$, no significant differences were seen amongst key flavour attributes such as Cocoa flavour, Bitterness, Total Fruity and Total Floral notes. Astringency scores ranged from 7.4 in beans dried continuously to 7.0 and 6.9 in beans dried intermittently, without and with turning. Total acidity scores were low, ranging from 2.4 to 3.6 .

\section{Conclusions}

Drying temperature had a significant impact on the drying rate and $\mathrm{pH}$ of beans dried continuously. Drying rates were optimized at $50^{\circ} \mathrm{C}$, with these beans being least acidic. Increasing the drying temperature to $60^{\circ} \mathrm{C}$ resulted in shrivelled beans which were most acidic. With the exception of beans dried at $40^{\circ} \mathrm{C}$, the introduction of a rest interval and turning of beans did not improve moisture loss. It is possible that improved moisture movement due to a rest interval during traditional sun-drying may be due to the low 
temperatures (below $50^{\circ} \mathrm{C}$ ) experienced during sun-drying, as well as the depth of bean layer during drying.

\section{Nomenclature}

$\begin{array}{ll}A & \text { - drying constant } \\ a_{w} & \text { - water activity } \\ D_{e f f} & \text { - diffusion coefficient }\left(\mathrm{m}^{2} / \mathrm{s}\right) \\ D M & \text { - dry matter }(\mathrm{g}) \\ E_{a} & \text { - activation energy }(\mathrm{J} / \mathrm{mol}) \\ F W & \text { - fresh weight }(\mathrm{g}) \\ k & \text { - drying rate constant }(1 / \mathrm{min}) \\ L & \text { - half-thickness of sample }(\mathrm{m}) \\ L^{*}, a^{*}, b^{*} \text { - colour attributes } \\ M & \text { - moisture content }\left(\mathrm{g} \mathrm{H}_{2} \mathrm{O} / \mathrm{g} \mathrm{DM}\right) \\ M R & \text { - moisture Ratio }\left(M-M_{\mathrm{e}} / M_{\mathrm{o}}-M_{\mathrm{e}}\right) \\ R^{2} & \text { - coefficient of determination } \\ e & \text { - equilibrium } \\ o & \text { - initial }\end{array}$

\section{Acknowledgement}

The authors would like to acknowledge the Campus Research and Publication Fund, Office of Graduate Studies and Research of the University of the West Indies, Saint Augustine Campus, for funding this research under the project: "The drying behaviour of sun and oven-dried cocoa (Theobroma cacao L.) beans and the impact of drying methods and drying parameters on bean quality."

\section{References}

[1] Hii, C.L. Modelling of the cocoa drying kinetics. Malaysian Cocoa Journal 2008, 4, 5159.

[2] Faborode, M.O.; Favier, J.F.; Ajayi, O.A. On the effects of forced air drying on cocoa quality. Journal of Food Engineering 1995, 25(4), 455-472.

[3] Ndukwu, M.C. Effect of drying temperature and drying air velocity on the drying rate and drying constant of cocoa bean. Agricultural Engineering International: CIGR Journal 2009, XI (1091), 1-7. 
[4] Chineye, N.M.; Ogunlowo, A.S.; Olukunle, O.J. Cocoa bean (Theobroma cacao L.) drying kinetics. Chilean Journal of Agricultural Research 2010, 70(4): 633-639.

[5] Musa, N.A. Drying characteristics of cocoa beans using an artificial dryer. Journal of Engineering and Applied Sciences 2012, 7(2), 194-197.

[6] Hii, C. L.; Law, C.L.; Cloke, M.; Suzannah, S. Thin layer drying kinetics of cocoa and product quality. Biosystems Engineering 2009, 102, 153-161.

[7] Hii, C. L.; Law, C.L.; Cloke, M. Modeling using a new thin layer drying model and product quality of cocoa. Journal of Food Engineering 2009, 90, 191-198.

[8] Zahouli, G.I.B.; Tagro Guehi, S.; Monké Fae, A.; Ban-Koffi, L.; Gnopo Nemlin, J. Effect of Drying Methods on the Chemical Quality Traits of Cocoa Raw Material. Advance Journal of Food Science and Technology 2010, 2(4), 184-190.

[9] Rodriguez-Campos, J.; Escalona-Buendía, H.B.; Contreras-Ramos, S.M.; Orozco-Avila, I.; Jaramillo-Flores, E.; Lugo-Cervantes, E. Effect of fermentation time and drying temperature on volatile compounds in cocoa. Food Chemistry 2012, 132(1), 277-288.

[10] Guehi, T.S.; Zahouli, I.B.; Ban-Koffi, L.; Fae, M.A.; Nemlin, J.G. Performance of different drying methods and their effects on the chemical quality attributes of raw cocoa material. International Journal of Food Science and Technology 2010, 45(8), 1564-1571.

[11] Mujaffar, S.; Sukha, D.; Ramroop, A. Comparison of the drying behavior of fermented cocoa (Theobroma cacao L.) beans dried in a cocoa house, greenhouse and mechanical oven. In Proceedings of the International Symposium on Cocoa Research, Lima, Peru, November 13-17, 2017; 1-7.

[12] Konica Minolta Sensing Incorporated. Precise Color Communication; Konica Minolta Sensing Incorporated: Osaka, Japan, 2003.

[13] Sukha, D.A.; Butler, D.R.; Umaharan, P.; Boult, E. The use of an optimized organoleptic assessment protocol to describe and quantify different flavour attributes of cocoa liquors made from Ghana and Trinitario beans. European Food Research and Technology 2008, 226(3), 405-413.

[14] Hii, C. L.; Law, C.L.; Suzannah, S. Drying kinetics of the individual layer of cocoa beans during heat pump drying. Journal of Food Engineering 2012, 108, 276-282.

[15] Jinap, S.; Thien, J.; Yap, T.N. Effect of drying on acidity and volatile fatty acids content of cocoa beans, Journal of the Science of Food and Agriculture 1994, 65(1), 67-75. 